\title{
Effects of the algicidal bacterium CZBC1 on microalgal and bacterial communities in shrimp culture
}

\author{
Xiaojuan $\mathrm{Hu}^{* *}$, Guoliang Wen**, Wujie Xu, Yu Xu, Haochang Su, Keng Yang, \\ Yunna Xu, Zhuojia Li, Yucheng Cao*
}

Key Laboratory of South China Sea Fishery Resources Exploitation and Utilization, Ministry of Agriculture and Rural Affairs; Key Laboratory of Fishery Ecology and Environment, Guangdong Province; South China Sea Fisheries Institute, Chinese Academy of Fishery Sciences, Guangzhou 510300, PR China

\begin{abstract}
Algicidal bacteria may play a role in controlling algal blooms. Previously, a Bacillus cereus strain (CZBC1) was shown to have specificity against harmful Cyanophyta. To elucidate the characteristics of microalgal and bacterial communities in shrimp culture associated with the algicidal bacterium CZBC1 and its combined use with the addition of organic carbon, we established a shrimp culture system in which the dominant macroalgal species were Oscillatoria chlorina (Cyanophyta) and Chlorella pyrenoidosa (Chlorophyta). We studied water-column microalgal and bacterial communities in control (GC), bacteria (GB), and bacteria-carbon (GBC) treatment groups at the mid-point (Day 28) and end (Day 56) of the experiment. The algicidal bacterium CZBC1 was able to regulate abundance of Cyanophyta on Days 28 and 56 in GB and GBC. Abundances of Cyanophyta on Days 28 and 56 in GB $(<0.44 \%)$ and GBC $(<0.37 \%)$ were significantly lower than that in GC (25.58 to $40.87 \%$ ), and those of Chlorophyta in GB (86.83 to $92.85 \%$ ) and GBC (99.63 to $99.94 \%$ ) were significantly higher than those in GC (52.52 to $67.35 \%$ ). Multiple linear stepwise regression analysis showed that the amount of applied algicidal bacterium CZBC1 had the most significant negative correlation with the abundance of Cyanophyta $(R=0.973, p<$ 0.01). On Days 28 and 56, the average well color development value (Biolog), bacterial count, and bacterial community structure were relatively stable in GB, while the addition of a carbon source increased the amount of bacteria and affected the composition of the bacterial community in GBC. Our findings suggest that algicidal bacteria can be used to regulate microalgal communities and stabilize the metabolic potential of bacterial communities in aquaculture.
\end{abstract}

KEY WORDS: Algicidal bacteria $\cdot$ Dominant species of microalgae $\cdot$ Bacterial communities · Carbon source $\cdot$ Cyanophyta

\section{INTRODUCTION}

Developing a stable and favorable microalgal community (Chlorophyta or Bacillariophyta) is important for the aquatic environment, particularly for maintaining good water quality (Primavera 1993, MullerFeuga 2000) and ensuring optimal growth and survival of aquaculture animals (Burford 1997). Notably, Cyanophyta are less desirable than Chlorophyta or

${ }^{*}$ Corresponding author: cyc_715@163.com

***These authors contributed equally to this work
Bacillariophyta (Boyd 1989), because excessive growth of Cyanophyta may result in toxins that are harmful not only for aquaculture animals but also with respect to seafood safety for humans (Niedzwiadek et al. 2012, Harke et al. 2016). In recent years, many researchers have shown that algicidal bacteria can control harmful algae and regulate the microalgal biomass of red tide species (Imai et al. 2001, Mayali \& Azam 2004, Sun et al. 2016). Yang et

() The authors 2019. Open Access under Creative Commons by Attribution Licence. Use, distribution and reproduction are unrestricted. Authors and original publication must be credited. 
al. (2013) isolated the algicidal bacterium SK-5, which can inhibit the growth of the diatom Skeletonema costatum. Amaro et al. (2005) identified algallytic marine bacteria strongly associated with the toxic dinoflagellate Alexandrium catenella. However, the application of algicidal bacteria in aquaculture has not been extensively studied.

Algicidal bacteria isolated from marine environments have been assigned to the genera Alteromonas, Bacillus, Cellulophaga, Cytophaga, Flavobacterium, Micrococcus, Planomicrobium, Pseudoalteromonas, Pseudomonas, Saprospira, Vibrio, and Zobellia, among others (Mayali \& Azam 2004). Mu et al. (2007) isolated the algicidal bacterium B5, identified as Bacillus fusiformis, and showed that this bacterium has algal-lysing effects on Microcystis aeruginosa, Chlorella sp. and Scenedesmus sp. Li et al. (2015) isolated an algicidal bacterial strain, Bacillus sp. Lzh-5, with strong algicidal activity against $M$. aeruginosa. The algicidal bacterium CZBC1, Bacillus cereus, was isolated from the phycosphere of Microcystis flosaquae in ponds and was shown to have algicidal effects on Oscillatoria sp. and Microcystis sp. (Wang et al. 2016), making it promising for applications in aquaculture.

Bacterial communities can distribute dissolved organic matter (DOM), increase nutrient availability, and affect many other environmental and ecological processes (González et al. 2000, Hu et al. 2017a). The structure of bacterial communities can reflect aquatic ecosystem status and is an important indicator in mariculture ecosystems (Yoza et al. 2007, Zhang et al. 2014). Furthermore, the function and metabolic characteristics of a culturable bacterial community can be characterized by analyzing sole carbon source utilization patterns (Weber \& Legge 2011). In recent years, biofloc technology has been developed as an environmentally friendly and sustainable approach in aquaculture, making it the focus of many researchers (Avnimelech 1999). Additional organic carbon sources are often added to manipulate the carbon/nitrogen ratio in water and promote the growth of heterotrophic bacteria in aquaculture (Crab et al. 2012). Hu et al. (2017b) confirmed that the combined use of Bacillus and molasses increased the diversity of the bacterial community, effectively inhibited pathogens, and promoted the formation and development of a beneficial bacterial community structure in high-density, intensive shrimp Litopenaeus vannamei aquaculture. Although the algicidal bacterium CZBC1 also belongs to the Bacillus genus, the effects of the combined use of algicidal bacteria and organic carbon on water column microalgal and bacterial communities remain unclear.
In this study, we aimed to elucidate the influence of the algicidal bacterium $\mathrm{CZBC} 1$, both alone and in combination with organic carbon, on water column microalgal and bacterial communities. To this end, we established a shrimp culture system with water containing algae, in which the dominant microalgae were Cyanophyta and Chlorophyta (Lee 2018). We studied the characteristics of water column microalgal and bacterial communities in control (GC), bacteria (GB), and bacteria-carbon (GBC) treatment groups at the mid-point (Day 28) and end (Day 56) of the experiment. Our findings provide useful information regarding the impact of the algicidal bacterium CZBC1 and its combined use with carbon sources on microalgal and bacterial communities. These findings could shed light on the potential applications of algicidal bacteria.

\section{MATERIALS AND METHODS}

\subsection{Experimental shrimp and tank system}

This study was conducted at the Shenzhen Experimental Station of South China Sea Fisheries Research Institute, the Chinese Academy of Fishery Sciences, China. The experimental system was composed of 12 polyethylene barrels (800 l each). At the start of the experiment, $500 \mathrm{l}$ of water containing $2.12 \times 10^{6}$ cells $\mathrm{ml}^{-1}$ algae was injected into the polyethylene barrels. The dominant species of microalgae were Chlorella pyrenoidosa and Oscillatoria chlorina, with initial densities of $7.90 \times 10^{5}$ and $9.40 \times 10^{5}$ cells ml${ }^{-1}$, respectively. Shrimp (Litopenaeus vannamei) for the experiment were obtained from the shrimp ponds of the Shenzhen Experimental Station. Average shrimp length was $7.27 \pm 1.02 \mathrm{~cm}$; average weight was $3.76 \pm$ $0.31 \mathrm{~g}$. The stocking density was 260 ind. $\mathrm{m}^{-3}$. The juvenile shrimps from the same shrimp pond were caught by trap net, and then were domesticated $1 \mathrm{wk}$ in the barrels before the experiment. During cultivation, the salinity of the water was $32-36 \mathrm{ppt}$, and water temperature ranged from $19.5-29.5^{\circ} \mathrm{C}$. The concentration of dissolved oxygen (DO) was maintained between 7.27 and $8.85 \mathrm{mg} \mathrm{l}^{-1}$, and the $\mathrm{pH}$ was kept between 7.2 and 7.9. The physicochemical factors of the water were suitable for $L$. vannamei.

\subsection{Algicidal bacteria}

The algicidal bacterium CZBC1, Bacillus cereus, has been granted a national invention patent in 
China (patent number ZL201310203745.3. CZBC1 has algicidal effects on harmful cyanobacteria and does not adversely affect shrimp; the survival rate of shrimp was $100 \%$ at $240 \mathrm{~h}$ after adding CZBC1 (Wang et al. 2016, Hu et al. 2017c).

In the experiment, the algicidal bacterium was prepared as a probiotic product which contained $5 \times 10^{9}$ colony forming units (CFU) $\mathrm{g}^{-1}$ of CZBC1. The probiotic product was provided by the Fermentation Engineering Center of South China Sea Fishery Research Institute, Chinese Academy of Fishery Sciences.

\subsection{Experimental design}

The experiment began when juvenile shrimp were stocked into the polyethylene barrels and lasted for $8 \mathrm{wk}$. A commercial feed (crude protein content: $40.1 \%$; crude lipid content: $7.0 \%$; fiber content: $3.5 \%$; ash content: $14.0 \%$ ) were fed to shrimps 3 times per day $(07: 00,13: 00$, and 19:00 h) by hand in equal portions.

The 12 barrels were divided into 3 equal groups (Table 1). GC was the control group, GB received the probiotic product of algicidal bacterium CZBC1 once every $7 \mathrm{~d}$ at $5 \times 10^{4} \mathrm{CFU} \mathrm{ml}{ }^{-1}$ based on the conventional usage of probiotics in aquaculture (Cao et al. 2014), and GBC received CZBC1 once every $7 \mathrm{~d}$ at $5 \times 10^{4} \mathrm{CFU} \mathrm{ml}{ }^{-1}$ and brown sugar every day. The amount of brown sugar added was $30 \%$ of the daily feed amount, and the $\mathrm{C} / \mathrm{N}$ ratio of the culture water was 12:1 (Xu et al. 2016).

The experiment was conducted for $56 \mathrm{~d}$. Remnant bait was removed regularly throughout the culture period. Initial rations were calculated based on an assumed growth rate of $1.0 \mathrm{~g} \mathrm{wk}^{-1}$, feed conversion ratio (FCR) of 1.2, and $90 \%$ survival. Rations were later adjusted based on daily observation of slight excess feeds on feeding trays ( 1 tray per tank) after $1.5 \mathrm{~h}$ of feeding.

Table 1. Experimental treatments examining the effect of adding algicidal bacteria (CZBC1) and carbon (brown sugar) on performance of Litopenaeus vannamei (GC: control; GB: bacteria; GBC: bacteria-carbon). CFU: colony forming units

\begin{tabular}{|lcccc|}
\hline & \multicolumn{2}{c|}{$\begin{array}{c}\text { Algicidal bacterium CZBC1 } \\
\text { Amount } \\
\left(\mathrm{CFU} \mathrm{ml}{ }^{-1}\right)\end{array}$} & Frequency & Brown sugar \\
& Amount & & & \\
\hline GC & - & - & - & - \\
GB & $5 \times 10^{4}$ & Weekly & - & - \\
GBC & $5 \times 10^{4}$ & Weekly & $\begin{array}{l}30 \% \text { of daily } \\
\text { feed amount }\end{array}$ & Daily \\
& & & reency \\
\hline
\end{tabular}

\subsection{Sampling}

Water samples were collected on Days 28 and 56 for analysis of microalgae, bacteria, and water quality. Mixed samples were taken from each barrel. All samples were stored at $0^{\circ} \mathrm{C}$ in a portable freezer and transported to the laboratory for analysis.

\subsection{Determination of shrimp performance}

After $56 \mathrm{~d}$, water in the tanks was drained for shrimp counting and weighing. Survival, growth rate (expressed as weekly weight gain), and feed conversion ratio (FCR) were calculated by using the following calculations: survival $(\%)=100 \times$ (final live shrimp count/initial stocking shrimp count); growth rate $\left(\mathrm{g} \mathrm{wk}^{-1}\right)=($ mean final weight of shrimp - mean initial weight of shrimp)/culture weeks; FCR = total weight of feed offered/total shrimp weight gained.

\subsection{Analysis of microalgae}

The 11 mixed water samples were collected and fixed in $5 \%$ formaldehyde solution for determination of the microalgae count. Microalgae were identified under a light microscope (Olympus CX41), and their cell densities were evaluated using a hemocytometer (Cremen et al. 2007). The identification and enumeration of microalgae were performed. The percentage of Cyanophyta was obtained by the equation: percentage $(\%)=100 \times($ density of Cyanophyta/density of microalgae). Similarly, the percentage of Chlorophyta was obtained by the equation: percentage $(\%)=100 \times$ (density of Chlorophyta/density of microalgae).

\subsection{Enumeration of bacteria and heterotrophic bacteria}

Approximately $50 \mathrm{ml}$ of the mixed sample was collected and fixed in $2 \%$ formaldehyde solution for determination of the bacterial count in water. The counting of bacteria was performed by staining with the DNA-intercalating dye 4', 6-diamidino-2-phenylindole (DAPI) (General Administration of Quality Supervision, Inspection and Quarantine of the People's Republic of China 2008a). Briefly, an appropriate quantity of sample was collected and filtered through a $0.2 \mu \mathrm{m}$ black polycarbonate membrane (Millipore Isopore; $25 \mathrm{~mm}$ ) under negative pressure $(50 \mathrm{kPa})$. This helped maintain a wet state, and the 
vacuum was then removed. Using a $0.2 \mu \mathrm{m}$ sterile filter in a sterile syringe, $1 \mathrm{ml}$ DAPI working liquid $\left(10 \mu \mathrm{g} \mathrm{ml}^{-1}\right)$ was added to the filter membrane along the filter cylinder wall. After staining for 5-10 min, the liquid was removed under similar negative pressure. The membrane was mounted on a microscopic slide under immersion oil, and bacterial cells were counted immediately using a fluorescence microscope (Olympus BX43). DNA-DAPI complex fluorescence appeared as a bright green color. A total of 10 fields with at least 30 bacteria field $^{-1}$ were counted.

Bacterial number ( $\mathrm{BN}$, cells $\mathrm{l}^{-1}$ ) was determined by the following equation:

$$
\mathrm{BN}=N_{\mathrm{a}} \times S /\left[S_{\mathrm{f}} \times(1-0.05) \times V\right]
$$

where $N_{\mathrm{a}}$ is the average bacterial count in the visual field, $S$ is the actual filtration area of the membrane, $S_{\mathrm{f}}$ is the area of the visual field of the microscope, and $V$ is the volume of the filtered water sample.

Another set of mixed water samples (about $100 \mathrm{ml}$ ) was collected in sterile sampling bottles and used to quantify heterotrophic bacteria and the metabolic potential of bacterial communities. Samples for heterotrophic bacteria were processed within $2 \mathrm{~h}$ after sampling, and 1 water sample enclosure ${ }^{-1}$ was tested, in triplicate, using marine agar 2216 (General Administration of Quality Supervision, Inspection and Quarantine of the People's Republic of China 2008a). CFU were counted after incubation at $28^{\circ} \mathrm{C}$ for $120 \mathrm{~h}$.

\subsection{Metabolic profiles of bacterial communities}

According to the sole carbon source utilization pattern, ECO microplates (Biolog) were used to determine the metabolic potential of water column bacterial communities. Each ECO microplate contained 3 replicate sets of 31 carbon substrates and a control (Choi \& Dobbs 1999). Each sample was inoculated into a microplate with $150 \mu \mathrm{l}$ well ${ }^{-1}$. Samples were incubated at $30^{\circ} \mathrm{C}$, and the absorbance at $590 \mathrm{~nm}$ was measured every $24 \mathrm{~h}$ for $168 \mathrm{~h}$ with a Biolog Microstation (Lee et al. 2010).

The average well color development (AWCD) indicates the potential utilization of various carbon sources by bacterial communities. AWCD values represent the overall carbon metabolism of the bacterial community. The change rate of AWCD reflects the metabolic activity of the bacteria (Choi \& Dobbs 1999). AWCD was calculated to compare controls and samples based on the optical density at $590 \mathrm{~nm}$ $\left(\mathrm{OD}_{590}\right)$ of each microplate well:

$$
\mathrm{AWCD}=[\Sigma(c-R)] / \mathrm{n}
$$

where $C$ is the $\mathrm{OD}_{590}$ of each cultured well, $R$ is the $\mathrm{OD}_{590}$ of the control well, and $n$ is the number of substrates (Garland \& Mills 1991).

\subsection{Structural characteristics of bacterial communities}

Additionally, 11 mixed water samples were used to study the structural characteristics of bacterial communities. The water samples were concentrated using $0.2 \mu \mathrm{m}$ membrane filters (Millipore) for DNA extraction. Genomic DNA was extracted from $1 \mathrm{l}$ of mixed water from each enclosure using an Omega EZNA Water DNA Kit (Omega Bio-Tek) according to the manufacturer's protocol. DNA was quantified using a NanoDrop 2000 spectrophotometer (Nano Drop Technologies) and stored at $-80^{\circ} \mathrm{C}$ until amplification. Then, $16 \mathrm{~S}$ amplicon sequencing was carried out by the Beijing Genomics Institute (BGI) for assignment of microbial species taxonomy in shrimp pond water samples. The following primers were used for the amplification of the 16S V4 region: $515 \mathrm{~F}$ (5'-GTG CCA GCM GCC GCG GTA A-3') and 806 R (5'-GGA CTA CHV GGG TWT CTA AT-3') (Caporaso et al. 2012). Polymerase chain reaction products were recycled to construct the library of amplicons, and sequencing was then performed on the MiSeq platform (Illumina). Tags were obtained by joining the reads according to the overlaps by fast length adjustment of short reads (FLASH, version 1.2.11; Mago \& Salzberg 2011). Barcode sequences and primer sequences were removed to obtain raw tags, and tags less than $200 \mathrm{bp}$ in length were removed to obtain clean tags, which were clustered into operational taxonomic units (OTUs) at a $97 \%$ identity level with USEARCH version 7.0.1090 (Edgar 2010). Taxonomies were assigned at the phylum, class, and order levels by comparison of OTU data with the Greengene database release 13.5 (http://greengenes. secondgenome.com/). Dissimilarity matrices with weighted UniFrac distances were estimated using the software package mothur (Schloss et al. 2009).

\subsection{Environmental properties}

The physicochemical variables of the water samples from each barrel were determined using a YSI 550 system for measurement of in situ salinity, temperature, $\mathrm{pH}$, and DO. Another $1 \mathrm{l}$ of mixed water 
samples was stored in glass bottles for the analysis of water quality. Concentrations of nutrients, including total carbon (TC), total organic carbon (TOC), and dissolved organic carbon (DOC), were also determined (General Administration of Quality Supervision, Inspection and Quarantine of the People's Republic of China 2008b).

\subsection{Statistical analysis}

Multiple linear stepwise regression analysis using SPSS 19.0 software (IBM) was used to analyze the relationships among Cyanophyta and other factors. The percentage of Cyanophyta (Cy-QP) was considered the dependent variable, and the other factors, including the amount of applied algicidal bacterium CZBC1 (AB-AA), the concentration of DOC, and the total quantity of microalgae (TM), were considered independent variables. After standardization, these data were analyzed by multiple linear stepwise regressions.

A multivariate ordination method was used to analyze the relationships between bacterial community structures and environmental variables in CANOCO version 4.5 (Biometris). De-trended correspondence analysis (DCA) was performed to test whether weighted-averaging techniques or linear methods were appropriate. The longest gradient resulting from DCA was 0.331. Accordingly, redundancy analysis (RDA) (Ter Braak \& Šmilauer 2002) was performed to select the environmental predictors that best explained the variance of bacterial communities.

Data are expressed with standard deviations. ANOVA was performed using SPSS 19.0 and differences with $p<0.05$ were considered significant.

\section{RESULTS}

\subsection{Shrimp performance}

Shrimp survival, final weight, growth rate, and FCR over the $56 \mathrm{~d}$ experimental period are presented in Table 2. Significantly higher survival, final weight, and growth rate were observed in GBC and GB than in GC ( $p<0.05)$, while significantly lower FCR was observed in GBC and GB compared to GC $(p<0.05)$, as the same amount of feed was provided to each group every day. Shrimp in GBC had higher survival, final weight, and growth rate than in GB $(\mathrm{p}<0.05)$.

\subsection{Dominant species of microalgae}

At the beginning of the experiment, the number of microalgal cells was $2.12 \times 10^{6}$ cells ml $^{-1}$ (Fig. 1). The dominant species were Chlorella pyrenoidosa $(37.26 \%)$ and Oscillatoria chlorina $(44.33 \%)$ belonging to the phyla Chlorophyta and Cyanophyta, respectively (Fig. 2). On Day 28, cells in GC, GB, and GBC numbered $2.80 \times 10^{6}, 1.50 \times 10^{6}$, and $1.43 \times 10^{5}$ cells ml ${ }^{-1}$, and on Day 56, $2.90 \times 10^{6}, 1.26 \times 10^{6}$, and $2.20 \times 10^{5}$ cells ml $^{-1}$, respectively (Fig. 1). On Day 28, percentages of Chlorophyta in GB and GBC were 86.83 and $99.63 \%$, respectively, which were significantly higher than that in GC $(67.35 \%$; p < 0.05) (Fig. 2A). In contrast, those of Cyanophyta in GB and GBC decreased from 44.33 to 0.44 and $0.37 \%$, respectively; these values were significantly lower than that in GC $(25.58 \%$; $<$ < 0.05) (Fig. 2B). The percentage of Chlorophyta in GC decreased to $52.52 \%$, whereas in GB and GBC it increased to 92.85 and $99.94 \%$, respectively (Fig. 2A). The percentage of

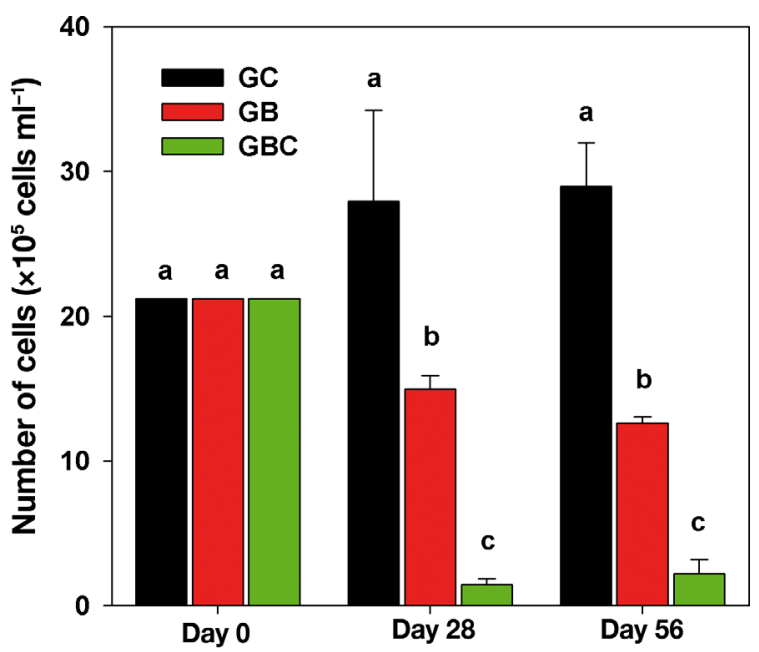

Fig. 1. Number of microalgae cells (mean \pm SD) in different groups (see Table 1) on Days 0, 28, and 56. Different lowercase letters indicate significant differences among treatment groups at the same sampling time (ANOVA, $\mathrm{p}<0.05$ ) 

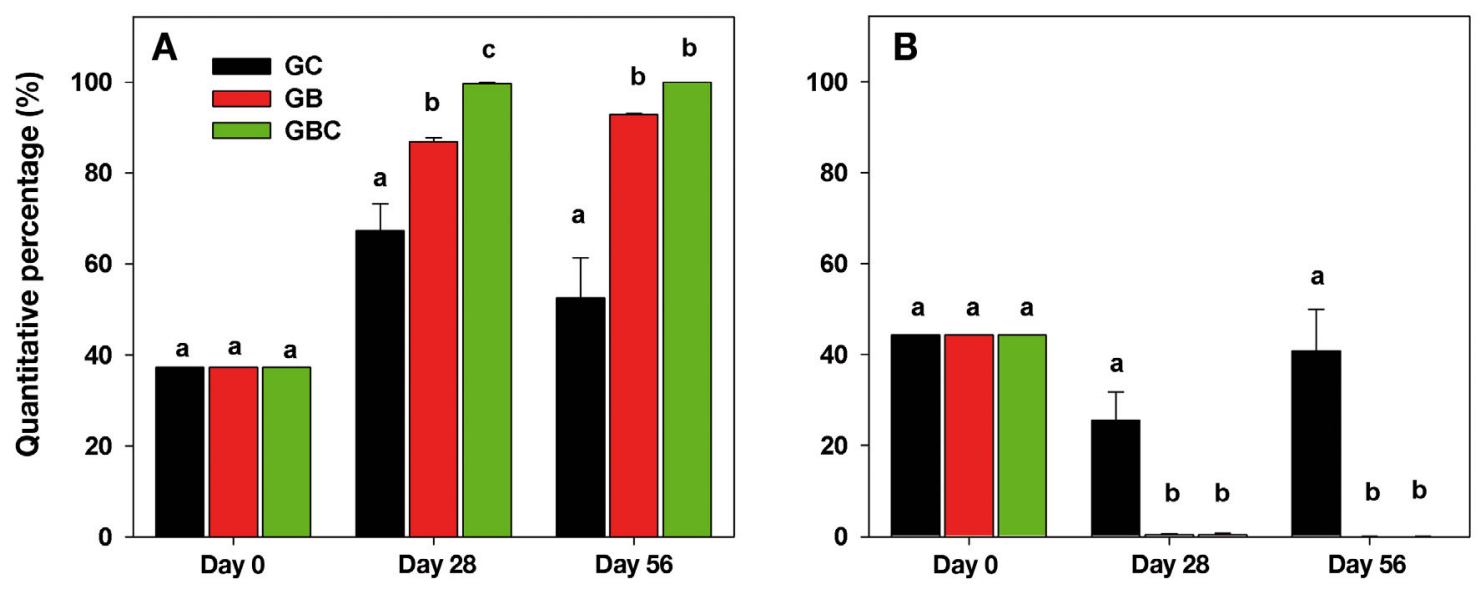

Fig. 2. Percentages (mean $\pm \mathrm{SD}$ ) of (A) Chlorophyta and (B) Cyanophyta among microalgae in different treatment groups (see Table 1) on Days 0, 28, and 56. Different lowercase letters indicate significant difference among groups at the same sampling time (ANOVA, $\mathrm{p}<0.05)$

Cyanophyta in GC increased to $40.87 \%$, which was significantly higher than in the other 2 groups $(\mathrm{p}<$ 0.05) (Fig. 2B).

\subsection{Total bacterial and heterotrophic bacterial counts}

There were no significant differences in the total bacterial counts between GC and GB ( $p>0.05)$; the counts ranged from $3.30 \times 10^{8}$ to $3.68 \times 10^{8} \mathrm{cells} \mathrm{ml}^{-1}$ on Days 28 and 56 (Fig. 3A). The total bacterial count in GBC ranged from $7.70 \times 10^{8}$ to $8.11 \times 10^{8}$ cells ml$^{-1}$, which was significantly higher than in the other 2 groups $(\mathrm{p}<0.05)$.

The heterotrophic bacterial count ranged from 3.97 $\times 10^{7}$ to $8.00 \times 10^{7} \mathrm{CFU} \mathrm{ml}^{-1}$ on Days 28 and 56
(Fig. 3B). The number of heterotrophic bacteria in GBC was significantly higher than in the other 2 groups $(\mathrm{p}<0.05)$.

\subsection{Metabolic potential of bacterial communities}

After $168 \mathrm{~h}$ of incubation, the AWCD of water column bacterial communities in each group maintained sustained growth (Fig. 4). There were no significant differences in AWCD values among the different groups on Day 28. With the extension of the culture period, the metabolic activity of the bacterial community in GC decreased gradually, the value at $168 \mathrm{~h}$ decreased from 1.19 on Day 28 to 0.66 on Day 56. In contrast, between Days 28 and 56, the bacterial communities of GB and GBC maintained relatively
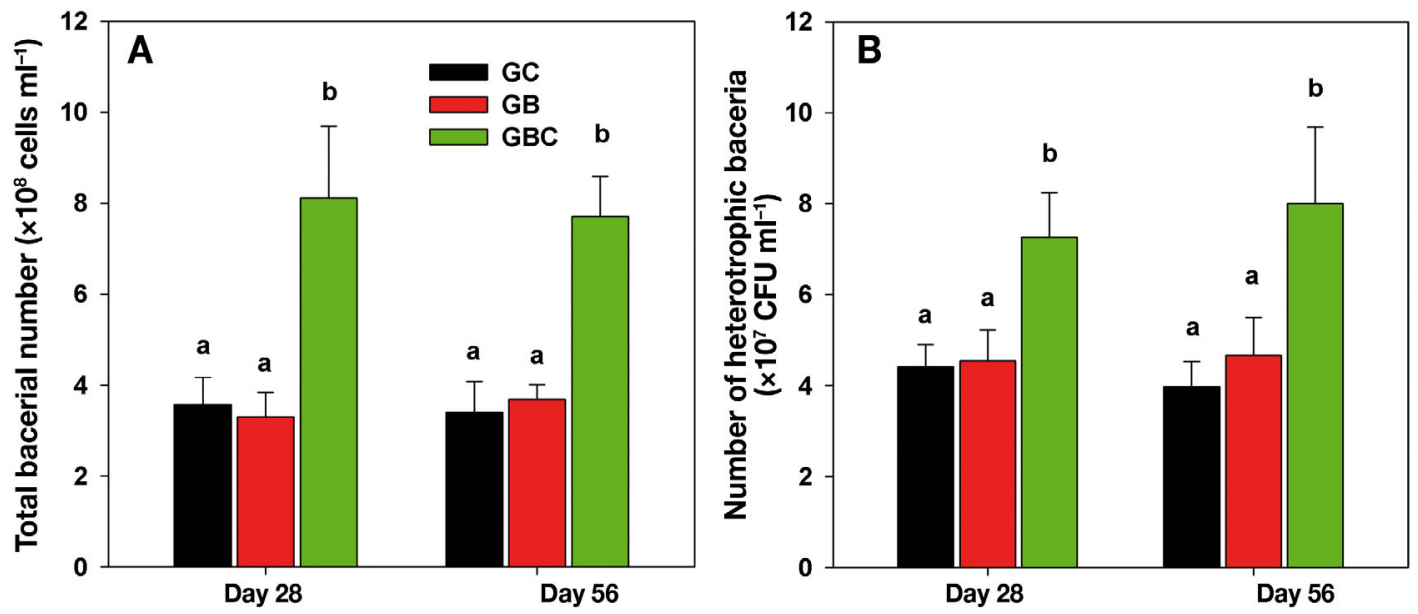

Fig. 3. Number (mean $\pm \mathrm{SD}$ ) of (A) total bacteria and (B) heterotrophic bacteria in different treatment groups (see Table 1) on Days 28 and 56. Different lowercase letters indicate significant differences among groups at the same sampling time (ANOVA, $\mathrm{p}<0.05$ ) 

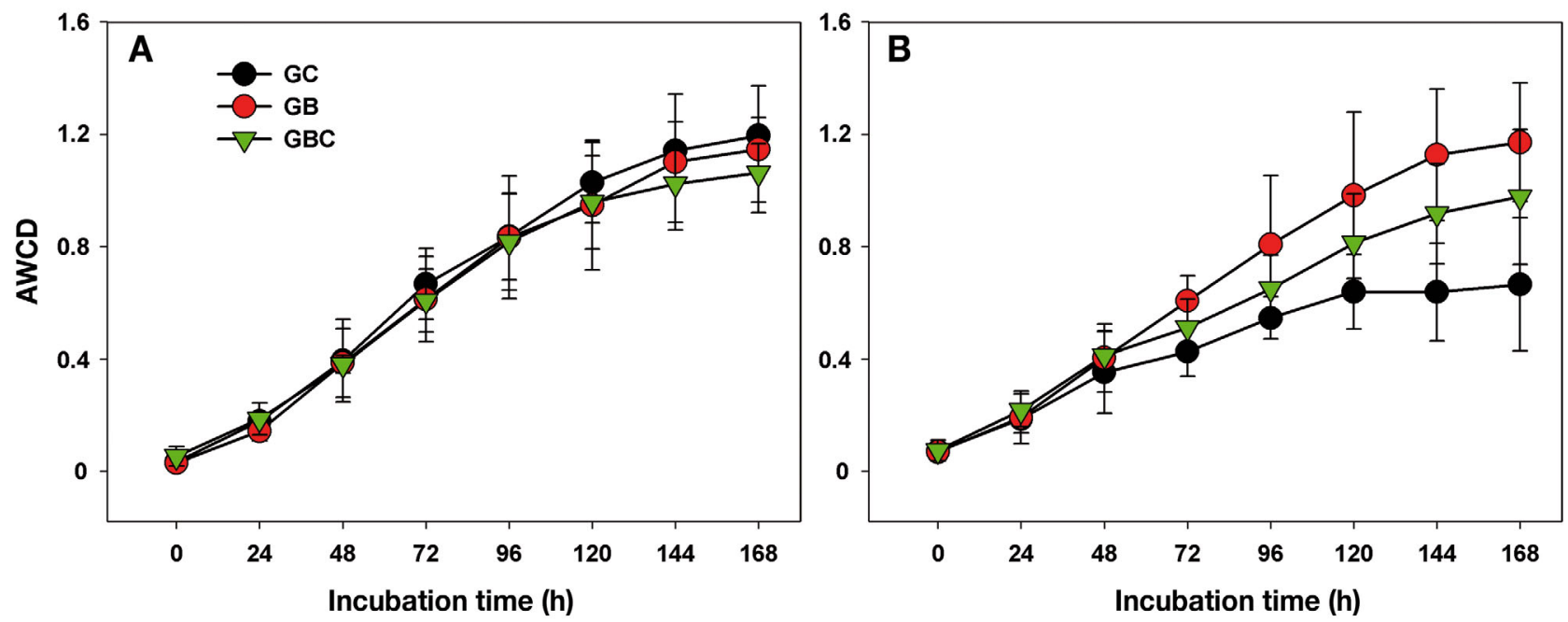

Fig. 4. Metabolic activity of the bacterial community in different treatment groups (see Table 1) on (A) Day 28 and (B) Day 56 . AWCD: average well color development. Data are mean \pm SD

stable metabolic activity, with AWCD values at $168 \mathrm{~h}$ between 1.15 and 1.17 and between 0.98 and 1.06, respectively (Fig. 4).

\subsection{Structural characteristics of bacterial communities}

In the GC treatment, the 3 most dominant bacterial phyla included the Bacteroidetes, Proteobacteria, and Planctomycetes on Day 28, with relative abundances of $62.03,24.30$, and $4.48 \%$, respectively (Fig. 5A). Proteobacteria included $\alpha$-Proteobacteria, $\gamma$-Proteobacteria, $\delta$-Proteobacteria, and $\varepsilon$-Proteobacteria, which accounted for $12.05,7.63,4.04$, and $0.08 \%$ of the total bacteria, respectively (Fig. 5B). On Day 56, the most dominant bacteria was Proteobacteria, with a relative abundance of $29.68 \%$; $\alpha$-Proteobacteria, $\gamma$-Proteobacteria, $\delta$-Proteobacteria, and $\varepsilon$-Proteobacteria accounted for $14.88,9.82,3.20$, and $1.10 \%$ of the total bacteria, respectively. Additionally, Bacteroidetes and Actinobacteria were detected at relative abundances of 27.88 and $11.74 \%$, respectively (Fig. 5).

In the GB treatment, the 3 most dominant bacteria belonged to Bacteroidetes, Proteobacteria, and Planctomycetes on Day 28, with relative abundances of 59.24, 26.20, and 6.01\%, respectively (Fig. 5A). Proteobacteria included $\alpha$-Proteobacteria, $\gamma$-Proteobacteria, $\delta$-Proteobacteria, and $\varepsilon$-Proteobacteria, which accounted for $15.86,7.18,2.44$, and $0.10 \%$ of the total bacteria, respectively (Fig. 5B). On Day 56, the most dominant bacteria was Proteobacteria, with a relative abundance of $30.43 \%$; $\alpha$-Proteobacteria, $\gamma$-Proteobacteria, $\delta$-Proteobacteria, and $\varepsilon$-Proteobacteria ac- counted for $17.32,10.00,1.57$, and $0.83 \%$ of the total bacteria, respectively. Additionally, Bacteroidetes and Actinobacteria were detected with relative abundances of 27.94 and $9.43 \%$, respectively (Fig. 5).

In the GBC treatment, the 3 most bacteria belonged to the Proteobacteria, Bacteroidetes, and Planctomycetes on Day 28, with relative abundances of 60.78, 23.39, and 9.20\%, respectively (Fig. 5A). Proteobacteria included $\alpha$-Proteobacteria, $\gamma$-Proteobacteria, $\delta$-Proteobacteria, and $\varepsilon$-Proteobacteria, which accounted for $44.26,11.19,4.65$, and $0.10 \%$ of the total bacteria, respectively (Fig. 5B). Furthermore, Rhodobacterales accounted for $30.06 \%$ of the total bacteria (Fig. 5C). On Day 56, the dominance of Proteobacteria further increased, with a relative abundance of $76.82 \%$ (Fig. 5A). Among these bacteria, $\gamma$-Proteobacteria, $\alpha$-Proteobacteria, $\delta$-Proteobacteria, and $\varepsilon$-Proteobacteria accounted for $60.12,14.26,1.72$, and $0.14 \%$ of the total bacteria, respectively (Fig. 5B). Additionally, Bacteroidetes and Planctomycetes showed relative abundances of 8.38 and $6.28 \%$, respectively. Furthermore, Alteromonadales accounted for $53.85 \%$ of the total bacteria (Fig. 5C).

\subsection{Beta diversity analysis based on weighted UniFrac distances}

Weighted UniFrac distances were computed to compare the similarities of the bacterial communities among different groups on Days 28 and 56 (Fig. 6), with higher indexes indicating greater differences between samples (Table 3). GB28 and GC28 (i.e. the bacteria and control groups on Day 28) clustered 



\section{C}



Acidimicrobiales Actinomycetales $\square$ Alteromonadales Bdellovibrionales Caldilineales $\square$ Campylobacterales

$\square$ Chroococcales

$\square$ Cytophagales

Flavobacteriales

$\square$ Kiloniellales

$\square$ Legionellales

Myxococcales

Oceanospirillales

$\square$ Phycisphaerales

$\square$ Pirellulales

Planctomycetales

Rhizobiales

$\square$ Rhodobacterales

Rhodospirillales

Rickettsiales

$\square$ Saprospirales

$\square$ Stramenopiles

$\square$ Thiotrichales

Verrucomicrobiales

$\square$ Vibrionales

$\square$ Unclassified

Others

Fig. 5. Structural characteristics of bacterial communities at the (A) phylum, (B) class, and $(\mathrm{C})$ order levels on Days 28 and 56. The $x$-axis labels represent treatment and day combinations (GC: control; GB: bacteria; GBC: bacteriacarbon treatment groups on Day 28 or 56) 


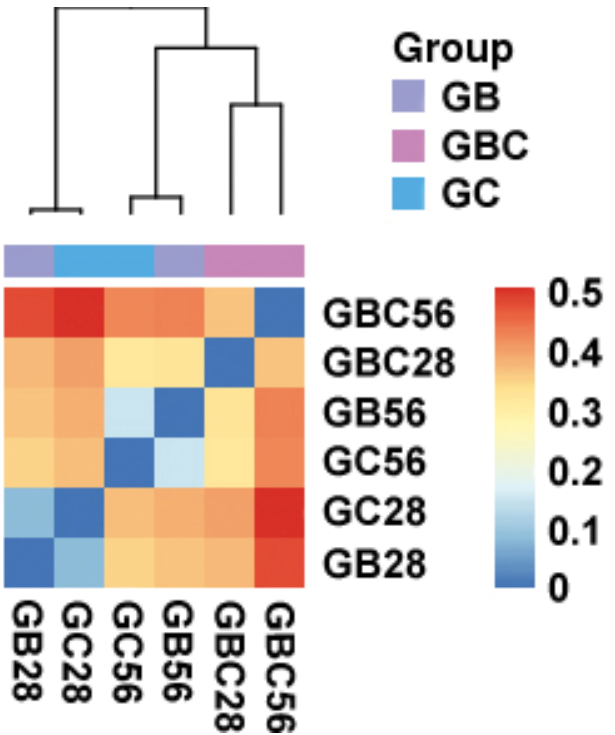

Fig. 6. Beta diversity analysis based on weighted UniFrac distances. Treatment (GC: control; GB: bacteria; GBC: bacteriacarbon groups) and day (Day 28 or 56) combinations are shown

Table 3. Distance matrix based on weighted UniFrac. Row and column headers represent treatment and day combinations (see Fig. 6)

\begin{tabular}{|lcccccc|}
\hline & GB28 & GB56 & GBC28 & GBC56 & GC28 & GC56 \\
\hline GB28 & 0 & 0.366 & 0.380 & 0.483 & 0.083 & 0.355 \\
GB56 & 0.366 & 0 & 0.327 & 0.435 & 0.389 & 0.150 \\
GBC28 & 0.380 & 0.327 & 0 & 0.367 & 0.402 & 0.323 \\
GBC56 & 0.483 & 0.435 & 0.367 & 0 & 0.512 & 0.427 \\
GC28 & 0.083 & 0.389 & 0.402 & 0.512 & 0 & 0.372 \\
GC56 & 0.355 & 0.150 & 0.323 & 0.427 & 0.372 & 0 \\
\hline
\end{tabular}

together, indicating high degrees of similarity in the bacterial communities between GB and GC on Day 28; the UniFrac distance was 0.083. A similar cluster was observed between GB56 and GC56, with a distance of 0.150 . In contrast, the UniFrac distance between GB56 and GBC56 was 0.367, indicating a certain degree of similarity between the bacterial communities.

\subsection{Variations in the carbon content in water samples}

As shown in Fig. 7, carbon levels remained high in the water samples in the GBC treatment because of the continuous addition of carbon. In particular, the concentrations of TC and DOC in GBC were significantly higher than those in the GC treatment on Day $56(\mathrm{p}<0.05)$.



Fig. 7. Variations in total carbon (TC), total organic carbon (TOC), and dissolved organic carbon (DOC) in different treatment groups (see Table 1) on Days 28 and 56. Different lowercase letters indicate significant difference among groups at the same sampling time (ANOVA, $p<0.05)$. Data are mean $\pm \mathrm{SD}$

\subsection{Multiple linear stepwise regression analysis}

The multiple regression equation that was used to illustrate the correlations among $\mathrm{Cy}-\mathrm{QP}, \mathrm{AB}-\mathrm{AA}$, the concentration of $\mathrm{DOC}$, and the TM is presented in Eq. (3). The regression coefficient of AB-AA was $-3.634(p=0.007)$, and those of DOC and TM were $-0.043(\mathrm{p}=0.966)$ and $0.166(\mathrm{p}=0.872)$, respectively. The relationship between $\mathrm{Cy}-\mathrm{QP}$ and $\mathrm{AB}-\mathrm{AA}$ was analyzed using linear stepwise regression (Eq. 4). From Eq. (4), the effects of AB-AA on CY-QP were the most significant, and a significant negative correlation was observed:

$$
\begin{gathered}
y_{\mathrm{CY}-\mathrm{Qp}}=-3.61 \times 10^{-5}-0.925 \mathrm{x}_{\mathrm{AB}-\mathrm{AA}}-0.006 \mathrm{x}_{\mathrm{DOC}} \\
+0.05 \mathrm{x}_{\mathrm{TM}}(\mathrm{R}=0.974, \mathrm{p}<0.01) \\
Y_{\mathrm{CY}-\mathrm{Qp}}=-4.101 \times 10^{-5}-0.973 \mathrm{x}_{\mathrm{AB}-\mathrm{AA}} \\
(\mathrm{R}=0.973, \mathrm{p}<0.01)
\end{gathered}
$$

\subsection{RDA}

RDA ordination was performed to correlate carbon content with bacterial communities on Days 28 and 56 (Fig. 8). With regard to the variance of the species data, the first axis explained $71.9 \%$ of the total variation, and the first and second axes explained $88.2 \%$ of the total variation. RDA showed that TC was positively correlated with the first axis. The carbon content in water significantly affected the bacterial com- 




Fig. 8. Redundancy analysis of bacterial community structure and carbon content on Days 28 and 56. Labels represent treatment and day combinations (see Fig. 6); DOC: dissolved organic carbon; TOC: total organic carbon; TC: total carbon

munity structure in GBC, particularly the dominant Proteobacteria. The bacterial communities in GC and GB were less affected by the carbon source.

\section{DISCUSSION}

Algicidal bacteria can inhibit algal growth or lyse cells directly by physical contact or indirectly by excreting active compounds (Guan et al. 2014, Li et al. 2015). To date, most studies have primarily assessed the algae-lysing characteristics of algicidal bacteria on harmful algae (Lovejoy et al. 1998, Mayali \& Azam 2004) from particular blooms or red tides; the effects of algicidal bacteria on the dominant species of algae in aquaculture ponds have not been sufficiently studied. Wang et al. (2016) analyzed the effects of CZBC1 on the microalgal community in shrimp aquaculture water using experimental ecology methods. The results showed that, after $15 \mathrm{~d}$ of culture, the percentage of Oscillatoria chlorina in the control group (81.86\%) was significantly higher than in Group J3 and Group J5 (16.7 and 14.6\%); initial bacterial numbers in these experimental groups with were $3.0 \times 10^{3}$ and $3.0 \times 10^{5} \mathrm{CFU} \mathrm{ml}^{-1}$, respectively. In contrast, the percentage of Oocystis borgei in the control group $(3.1 \%)$ was significantly lower than in the other 2 bacterial groups (32.4 and $47.1 \%$ ). In our study, the algicidal specificity of CZBC1 was also demonstrated. On Days 28 and 56 in the GB and GBC groups, the dominant microalgae changed from Cyanophyta $(44.33 \%)$ and Chlorophyta $(37.26 \%)$ to just Chlorophyta (>90\%). Moreover, the number of microalgal cells on Days 28 and 56 was lower than the initial number in GBC. It can be deduced that microbial bioflocs formed in the experimental tanks might indirectly control microalgae by regulating nutrients and/or secreting allelochemicals that inhibited the growth of algae (Wu et al. 2011, 2014, Sun et al. 2018). The results of multiple linear stepwise regression analysis showed that AB-AA had a significant negative effect on Cy-QP, indicating that the algicidal bacterium CZBC1 exhibited strong algicidal effects against harmful cyanobacteria and promoted the growth of Chlorophyta when no organic carbon was added. When organic carbon was added (treatment GBC), the absolute number of Chlorophyta actually decreased (although it remained dominant); the biofloc formation could be the cause.

Given the important ecological roles of the bacterial community, the influence of CZBC1 on the bacterial community was analyzed. Our results showed that there was no significant difference in the total and heterotrophic bacterial counts between the GB and GC treatment groups on Days 28 and 56. The structural characteristics of the bacterial communities in GB and GC indicated high degrees of similarity. Furthermore, the bacterial community of GB showed relatively stable metabolic activity. From these results, we concluded that, after the continuous use of algicidal bacteria, the bacterial count, AWCD values, and structural characteristics of the bacterial communities were relatively stable on Days 28 and 56.

Crab et al. (2012) showed that the growth of heterotrophic bacteria in aquaculture was promoted by adding organic carbon sources. Our results showed that the amounts of total bacteria and heterotrophic bacteria in GBC were significantly higher than those in GC and GB on Days 28 and 56. Avnimelech et al. (1994) and Browdy et al. (2001) found that manipulating water quality via the addition of carbon could shift the system from autotrophic to heterotrophic. Heterotrophic bacterial growth is stimulated, and nitrogen uptake occurs through the production of microbial proteins in response to the addition of carbohydrates to the water (Avnimelech 1999). Furthermore, we also found that the composition of the bacterial community structure had changed after adding organic carbon, although the community showed a high degree of similarity between GB and GC. RDA also showed that the carbon content in water significantly affected the 
bacterial community structure in GBC, particularly that of the dominant Proteobacteria. Moreover, Proteobacteria and Bacteroidetes, the dominant bacteria in $\mathrm{GBC}$, were also the dominant bacteria in shrimp culture enclosure systems subject to the combined use of Bacillus and molasses (Hu et al. 2017b). Thus, this treatment may play a key role in the carbon and nitrogen cycle (Sun et al. 2014). Our findings indicate that the algicidal bacterium CZBC1 exerts strong algicidal effects against harmful Cyanophyta (i.e. O. chlorina) and maintains the dominance of Chlorophyta, such as C. pyrenoidosa. The addition of the carbon source increased the number of bacteria in the water and altered the bacterial community structure on Days 28 and 56.

Based on these findings, algicidal bacteria show the potential to alter microalgal communities. Future gains in any commercial probiotics derived from algicidal bacteria may allow their use within aquaculture to control harmful algae.

Acknowledgements. This research was supported by program of China Agriculture Research System (CARS-48); Central Public-interest Scientific Institution Basal Research Fund, CAFS (2017HY-ZD0501); Fund of Key Laboratory of South China Sea Fishery Resources Exploitation \& Utilization, Ministry of Agriculture, PR China (FREU2015-08); and Special funds for Fishery Harbour Construction and Fishery Development of Guangdong Province (A201701B06). The authors thank the staff of Shenzhen Experimental Station for their efforts throughout the study.

\section{LITERATURE CITED}

Amaro AM, Fuentes MS, Ogalde SR, Venegas JA, SuárezIsla BA (2005) Identification and characterization of potentially algal-lytic marine bacteria strongly associated with the toxic dinoflagellate Alexandrium catenella. J Eukaryot Microbiol 52:191-200

Avnimelech Y (1999) Carbon/nitrogen ratio as a control element in aquaculture systems. Aquaculture 176:227-235

Avnimelech Y, Kochva M, Diab S (1994) Development of controlled intensive aquaculture systems with limited water exchange and adjusted carbon to nitrogen ratio. Israeli J Aquacult 46:119-131

Boyd CE (1989) Water quality management and aeration in shrimp farming. Fisheries and Allied Aquaculture Departmental Series No. 2. Alabama Agricultural Experiment Station, Auburn University, Auburn, AL

Browdy CL, Bratford D, Stokes AD, Mcintosh RP (2001) Perspectives on the application of closed shrimp culture systems. The World Aquaculture Society, Baton Rouge, LA

Burford M (1997) Phytoplankton dynamics in shrimp ponds. Aquacult Res 28:351-360

Cao YC, Wen GL, Li ZJ, Liu XZ, Hu XJ, Zhang JS, He JG (2014) Effects of dominant microalgae species and bacterial quantity on shrimp production in the final culture season. J Appl Phycol 26:1749-1757
Caporaso JG, Lauber CL, Walters WA, Berglyons D and others (2012) Ultra-high-throughput microbial community analysis on the Illumina HiSeq and MiSeq platforms. ISME J 6:1621-1624

Choi KH, Dobbs FC (1999) Comparison of two kinds of Biolog microplates (GN and ECO) in their ability to distinguish among aquatic microbial communities. J Microbiol Methods 36:203-213

Crab R, Defoirdt T, Bossier P, Verstraete W (2012) Biofloc technology in aquaculture: beneficial effects and future challenges. Aquaculture 356-357:351-356

* Cremen MCM, Martinez-Goss MR, Corre VL Jr, Azanza RV (2007) Phytoplankton bloom in commercial shrimp ponds using green-water technology. J Appl Phycol 19: 615-624

Edgar RC (2010) Search and clustering orders of magnitude faster than BLAST. Bioinformatics 26:2460-2461

Garland JL, Mills AL (1991) Classification and characterization of heterotrophic microbial communities on the basis of patterns of community-level sole-carbon-source utilization. Appl Environ Microbiol 57:2351-2359

General Administration of Quality Supervision Inspection and Quarantine of the People's Republic of China (2008a) GB/T 12763.6-2007. Specifications for oceanographic survey - part 6: marine biological survey. Standardization Administration of China, Beijing

General Administration of Quality Supervision Inspection and Quarantine of the People's Republic of China (2008b) GB/T 17378.4-2007. Specifications for marine monitoring - part 4: seawater analysis. Standardization Administration of China, Beijing

* González JM, Simó R, Massana R, Covert JS, Casamayor EO, Pedrósalió C, Moran MA (2000) Bacterial community structure associated with a dimethylsulfoniopropionateproducing North Atlantic algal bloom. Appl Environ Microbiol 66:4237-4246

*Guan CW, Guo XY, Cai GJ, Zhang HJ, Li Y, Zheng W, Zheng TL (2014) Novel algicidal evidence of a bacterium Bacillus sp. LP-10 killing Phaeocystis globosa, a harmful algal bloom causing species. Biol Control 76:79-86

Harke MJ, Steffen MM, Gobler CJ, Otten TG, Wilhelm SW, Wood SA, Paerl HW (2016) A review of the global ecology, genomics, and biogeography of the toxic cyanobacterium, Microcystis spp. Harmful Algae 54:4-20

* $\mathrm{Hu}$ XJ, Wen GL, Cao YC, Gong YX, Li ZJ, He ZL, Yang YF (2017a) Metabolic and phylogenetic profiles of microbial communities from a mariculture base on the Chinese Guangdong coast. Fish Sci 83:465-477

* Hu XJ, Cao YC, Wen GL, Zhang XY and others (2017b) Effect of combined use of Bacillus and molasses on microbial communities in shrimp cultural enclosure systems. Aquacult Res 48:2691-2705

$\mathrm{Hu}$ XJ, Xu CW, Li ZJ, Wen GL and others (2017c) Fermentation culture technique of cyanobacteria algae-lysing bacteria CZBC1 optimized by response surface method. Nanfang Nongye Xuebao 48:2092-2099

Imai I, Sunahara T, Nishikawa T, Hori Y, Kondo R, Hiroishi S (2001) Fluctuations of the red tide flagellates Chattonella spp. (Raphidophyceae) and the algicidal bacterium Cytophaga sp. in the Seto Inland Sea, Japan. Mar Biol 138:1043-1049

Lee RE (2018) Phycology, $5^{\text {th }}$ edn. Cambridge University Press, Cambridge

Lee EH, Kim J, Kim JY, Koo SY and others (2010) Comparison of microbial communities in petroleum-contaminated 
groundwater using genetic and metabolic profiles at Kyonggi-Do, South Korea. Environ Earth Sci 60:371-382

Li ZH, Geng MX, Yang H (2015) Algicidal activity of Bacillus sp. Lzh-5 and its algicidal compounds against Microcystis aeruginosa. Appl Microbiol Biotechnol 99:981-990

Lovejoy C, Bowman JP, Hallegraeff GM (1998) Algicidal effects of a novel marine Pseudoalteromonas isolate (class Proteobacteria, gamma subdivision) on harmful algal bloom species of the genera Chattonella, Gymnodinium, and Heterosigma. Appl Environ Microbiol 64:2806-2813

Mago T, Salzberg S (2011) FLASH: fast length adjustment of short reads to improve genome assemblies. Bioinformatics 27:2957-2963

Mayali X, Azam F (2004) Algicidal bacteria in the sea and their impact on algal blooms. J Eukaryot Microbiol 51: 139-144

Mu RM, Fan ZQ, Pei HY, Yuan XL, Liu SX, Wang XR (2007) Isolation and algae-lysing characteristics of the algicidal bacterium B5. J Environ Sci (China) 19:1336-1340

Muller-Feuga A (2000) The role of microalgae in aquaculture: situation and trends. J Appl Phycol 12:527-534

Niedzwiadek B, Scott PM, Lau BP (2012) Monitoring of shrimp and farmed fish sold in Canada for cyanobacterial toxins. J Food Prot 75:160-163

Primavera JH (1993) A critical review of shrimp pond culture in the Philippines. Rev Fish Sci 1:151-201

Schloss PD, Westcott SL, Ryabin T, Hall JR and others (2009) Introducing mothur: open-source, platform-independent, community-supported software for describing and comparing microbial communities. Appl Environ Microbiol 75:7537-7541

Sun F, Wang Y, Wu M, Wang Y, Qian P (2014) Spatial and vertical distribution of bacteria in the Pearl River estuary sediment. Afr J Biotechnol 11:2256-2266

Sun HY, Zhang Y, Chen HR, Hu CX, Li H, Hu ZL (2016) Isolation and characterization of the marine algicidal bacterium Pseudoalteromonas S1 against the harmful alga

Editorial responsibility: Alejandro Buschmann,

Puerto Montt, Chile
Akashiwo sanguinea. Mar Biol 163:66

Sun R, Sun P, Zhang J, Esquivel-Elizondo S, Wu Y (2018) Microorganisms-based methods for harmful algal blooms control: a review. Bioresour Technol 248:12-20

Ter Braak CJF, Šmilauer P (2002) CANOCO reference manual and CanoDraw for Windows user's guide: software for canonical community ordination (version 4.5). Microcomputer Power, Ithaca, NY

Wang SL, Cao YC, Xu Y, Hu XJ, Li ZJ, Wu Y (2016) Regulation of Bacillus cereus to microalgae community in shrimp aquaculture water. Nanfang Shuichan Kexue 12:9-16

*Weber KP, Legge RL (2011) Dynamics in the bacterial community-level physiological profiles and hydrological characteristics of constructed wetland mesocosms during start-up. Ecol Eng 37:666-677

* Wu YH, Liu JT, Yang LZ, Chen H, Zhang SQ, Zhao HJ, Zhang NM (2011) Allelopathic control of cyanobacterial blooms by periphyton biofilms. Environ Microbiol 13:604-615

Wu YH, Xia LZ, Yu ZQ, Shabbir S, Kerr PG (2014) In situ bioremediation of surface waters by periphytons. Bioresour Technol 151:367-372

* Xu WJ, Morris TC, Samocha TM (2016) Effects of C/N ratio on biofloc development, water quality, and performance of Litopenaeus vannamei juveniles in a biofloc-based, high-density, zero-exchange, outdoor tank system. Aquaculture 453:169-175

*Yang YF, Hu XJ, Zhang J, Gong YX (2013) Community level physiological study of algicidal bacteria in the phycospheres of Skeletonema costatum and Scrippsiella trochoidea. Harmful Algae 28:88-96

Y Yoza BA, Harada RM, Nihous GC, Li QX, Masutani SM (2007) Impact of mariculture on microbial diversity in sediments near open ocean farming of Polydactylus sexfilis. Ecol Indic 7:108-122

* Zhang D, Wang X, Xiong J, Zhu J and others (2014) Bacterioplankton assemblages as biological indicators of shrimp health status. Ecol Indic 38:218-224

Submitted: May 14, 2018; Accepted: April 5, 2019

Proofs received from author(s): June 7, 2019 